\title{
STRATEGI PEMERTAHANAN BAHASA SUNDA LEA INDRAMAYU
}

Sunda Lea Indramayu Language Maintenance Strategy

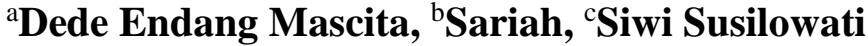 \\ ${ }^{a}$ Universitas Swadaya Gunung Jati Cirebon \\ ${ }^{\mathrm{b}, \mathrm{c}}$ Mahasiswa Pascasarjana Unswagati \\ dedenmas68@gmail.com
}

Naskah Diterima Tanggal 14 Oktober 2019-Direvisi Akhir Tanggal 23 April 2021_Disetujui Tanggal 1 Juni 2021 doi: https://doi.org/10.26499/rnh.v10i1.2395

\begin{abstract}
Abstrak
Bahasa Sunda Lelea merupakan bahasa Sunda yang berbeda apabila dibandingkan dengan bahasa Sunda utama yang berada di daerah priangan. Fokus penelitian ini adalah bagaimana pemertahanan bahasa Sunda Lea di antara penggunaan bahasa Jawa Dermayon yang berkembang di wilayah Indramayu, dan bahasa Indonesia. Penelitian ini berusaha mendeskripsikan data dan fakta upaya pemertahanan bahasa Sunda Lelea baik berupa penggunaan bahasa dalam kegiatan berbahasa masyarakatnya, maupun kebijakan-kebijakan yang dikeluarkan pemerintah desa setempat berkaitan dengan penggunaan bahasa sebagai alat berkomunikasi antarwarga. Penelitian ini menggunakan metode deskriptif kualitatif. Berdasarkan hasil analisis terhadap data yang diperoleh, disimpulkan bahasa Sunda Lea adalah salah satu bahasa daerah yang terbentuk dari bahasa Sunda dan bahasa Jawa Dermayon (Indramayu). Dalam upaya pemertahanannya, masyarakat dan pemerintah desa melakukan sosialisasi bahasa seperti: 1) dalam kegiatan keagamaan: pengajian dan khutbah Jumat; 2) pendidikan: KBM di sekolah umum dan madrasah; 3) pelayanan pemerintahan desa: kegiatan rapat, penyuluhan ke warga; 4) kebudayaan: perayaan acara adat, misalnya upacara Ngarot dan pernikahan; 5) PKK: arisan ibu-ibu; dan 6) kepemudaan: acara karang taruna.
\end{abstract}

Kata-kata kunci: bahasa Sunda Lea, pemertahanan bahasa, strategi

\begin{abstract}
This study aims to describe the efforts to maintenance Lea (Lelea) Sundanese language in Lelea Village, Indramayu. Lea Sundanese language is a different Sundanese language when compared to the main Sundanese in the Priangan area. The focus of this research is how to maintenance Lea Sundanese between the use of the Dermayon Javanese language that developed in the Indramayu region and Indonesian as the national language. This study seeks to describe the data and facts that the efforts to maintain the Sundanese Lelea language both in the form of language use in the language activities of the community, as well as policies issued by the local village government relating to the use of language as a means of communication between residents. Based on the results of the analysis of the data obtained it was concluded that Lea Sundanese is one of the regional languages formed from Sundanese and Javanese Dermayon (Indramayu). In their efforts to keep them prisoner, the community and village government carry out language socialization such as: 1) in religious activities: recitation and Friday sermons; 2) education: KBM in schools and madrasah; 3) village government services: meeting activities, counseling to residents; 4) culture: celebrations of traditional events, for example: Ngarot and marriage; 5) PKK: mothers' social gathering; and 6) youth: youth program.
\end{abstract}

Key words: Lea Sundanese, language maintenace, strategy 
How to Cite: Mascita, Dede Endang, Sariah, dan Siwi Susilowati. (2021). Strategi Pemertahanan Bahasa Sunda Lea Indramayu. Ranah: Jurnal Kajian Bahasa. 10(1). 182-195. doi: https://doi.org/10.26499/rnh.v10i1.2395

\section{PENDAHULUAN}

Bahasa daerah di Indonesia hampir mencapai jumlah 740-an atau sekitar 748 menurut sumber Wikipedia.com. Jumlah ini tentu saja yang tercatat. Dari sekian banyak bahasa daerah tersebut secara perlahan mengalami pengurangan karena adanya pergeseran dan perubahan bahasa oleh penggunanya karena berbagai faktor. Salah satu faktornya adalah pengaruh dari bahasa pendatang. Proses pengaruh-memengaruhi di antara bahasa tersebut tidak dapat dihindarkan. Besarnya pengaruh itu tentu saja ditentukan oleh berbagai faktor. Mackey (Wijana, 2006) mengatakan bahwa pengaruh itu didasarkan pada indikator geolinguistik, pesebaran, ekonomi, kultural, dan ideologi. Sehubungan dengan itu, permainan kata antarbahasa hanya terjadi pada suatu bahasa, tetapi tidak sebaliknya. Oleh karena itu, bahasa daerah yang memiliki nilai kearifan lokal suatu daerah sebagai warisan para leluhurnya harus dipertahankan dari kepunahannya.

Dari sekian banyak bahasa daerah adalah bahasa Lelea. Bahasa Lelea atau lebih dikenal dengan sebutan bahasa Lea adalah sebuah bahasa daerah yang berkembang di Desa Lelea. Bahasa Lea terbentuk dari percampuran dua bahasa, yaitu bahasa Sunda dan bahasa Jawa Indramayu. Bahasa ini menjadi sebuah bahasa yang menjadi alat komunikasi antarmasyarakat yang bersatu akibat adanya migrasi masyarakat Sunda ke wilayah masyarakat berbahasa Jawa. Fenomena yang terjadi, bahasa ini digunakan dalam setiap kegiatan masyarakat Desa Lelea khusunya dalam kegiatan budaya yang disebut dengan Ngarot. Fenomena lain adalah adanya upaya pemertahanan bahasa Lea menjadi bahasa pengantar dalam kegiatan kemasyarakatan di daerah tersebut. Hal inilah yang menarik untuk diteliti, yaitu sebuah bahasa baru, tetapi diupayakan oleh masyarakatnya untuk dipertahankan.

Hasil penelusuran penelitian terdahulu mengenai pemertahanan bahasa adalah penelitian Endang Nurhayati, dkk. (2013) berjudul Strategi Pemertahanan Bahasa Jawa di Provinsi Daerah Istimewa Yogyakarta yang menyimpulkan bahwa strategi pemertahanan bahasa Jawa adalah: (a) sebagai alat komunikasi, (b) penyatuan bahasa dan budaya, (c) kearifan lokal, (d) kebijakan Pemda, (e) dunia pendidikan, (g) kegiatan LSM, dan (h) jurnalistik Jawa. Yang lainnya adalah hasil kajian dari T. Fatimah Djaja Sudarma dkk (2015) yang berjudul Upaya Pemertahanan Bahasa-Budaya Sunda di Tengah Pengaruh Globalisasi yang diwujudkan dalam bentuk pelatihan kompetensi pendidik melalui pembelajaran bahasa daerah berbasis karakter. Norsimah Mat Awala, dkk., meneliti pemertahan bahasa ibu di perbatasan Malaysia dan Thailand dalam penelitiannya yang berjudul Maintenance of Mother Tongue: Patterns of Language Choice at the Malaysian-Thai Border. Penelitian lainnya yang dilakukan oleh Carla Paciotto dalam judul penelitianya, A Case Study of a Minority Language Maintenance Program in Italy: Students' and Teachers' Perspectives on the Slovene-Medium School Network. Penelitiannya menggambarkan bagaimana mempertahankan bahasa minoritas di Italia.

Penelitian lainnya mengenai pemertahanan bahasa adalah yang dilakukan Kholidah, U. (2015) berjudul Pemertahanan Bahasa Jawa pada Interaksi Siswa dan Guru dalam Pembelajaran Kajian Sosiolinguistik di MTs Al-Hikmah Pasir Demak. Dalam penelitiannya menghasilkan dua simpulan, yaitu yang pertama adalah pola pemertahanan bahasa pada interaksi pelajar dengan pengajar di MTs Al-Hikmah Pasir Demak berupa tiga pola adalah (1) pola hubungan pelajar dengan guru, (2) pola hubungan guru dengan pelajar, dan (3) pola hubungan pelajar dengan pelajar. Lalu, simpulan penelitian kedua adalah faktor yang memengaruhi adanya pemertahanan bahasa Jawa dalam interaksi pelajar dengan pengajar 
adalah faktor geografis, situasional, dan kesinambungan pengalihan (transmisi) bahasa Jawa dari generasi ke generasi berikutnya. Hasil penelitian Kholidah ini menunjukkan bahwa pemertahanan bahasa dapat dilakukan pada lingkungan sekolah (pendidikan) dan lingkungan keluarga. Penelitian pemertahanan bahasa dilakukan juga oleh Mujid FA dan Suyanto (2017) dengan judul Pergeseran dan Pemertahanan Bahasa Ibu Dalam Ranah Rumah Tangga Migran di Kota Semarang. Hasil penelitiannya menyebutkan ada beberapa migran yang masih mempertahankan bahasa ibunya yaitu pada kalangan migran tradisional yang bertempat tinggal di daerah perkampungan di daerah Semarang.

Penelitian Mujid ini menunjukkan bahwa kaum pendatang yang menggunakan bahasa minoritas tetap mempertahankan bahasa ibunya di lingkungan bahasa pribumi. Ini wujud kecintaan mereka terhadap bahasa leluhurnya. Pada tahun 2018, Putri, R.A. dkk melakukan penelitian di daerah Sedahan Jaya dengan fokus pada pemertahanan bahasa Bali. Penelitiannya itu menghasilkan simpulan bahwa masyarakat di Desa Sedahan Jaya berupaya melakukan pemertahanan bahasa Bali sebagai bahasa minoritas melalui ranah agama dan ranah keluarga. Pada tahun yang sama, Widianto (2018) melakukan penelitian yang berjudul Pemertahanan Bahasa Daerah Melalui Pembelajaran dan Kegiatan di Sekolah. Hasil penelitiannya menyimpulkan bahwa pemertahanan bahasa daerah dapat dilakukan melalui pendidikan. Wujud dari pemertahanannya adalah melalui pembelajaran, kegiatan komunitas/ekstrakurikuler, dan sebagai alat komunikasi wajib pada hari tertentu. Simpulan dari Widianto ini menegaskan cara pemertahanan yang dijelaskan Kholidah, yaitu melalui pendidikan. Pada tahun yang sama, Muslihah, N.N, Rusmana Dewi, Lessy Puspitasari (2018) melakukan penelitian yang berjudul Pemertahanan Bahasa Sindang pada Masyarakat Kota Lubuklinggau. Penelitian tersebut menyimpulkan bahwa sikap pemertahanan bahasa Sindang pada kelompok dewasa lebih kuat dibandingkan dengan kelompok remaja. Hal ini menunjukkan bahwa kelompok dewasa lebih kuat dalam mempertahankan bahasa Sindang sebagai bahasa asli penduduk Lubuklinggau. Simpulan hasil penelitian Muslihah ini menekankan pada kelompok orang dewasa yang dapat melakukan pemertahanan bahasa. Hal ini dapat dipahami bahwa masyarakat bahasa di usia anak-anak masih dapat dipengaruhi dalam penggunaan bahasanya. Selain itu, terdapat penelitian yang dilakukan oleh Santi Yulianti dan Winci Firdaus (2020) yang berkaitan dengan penggunaan bahasa, yaitu masalah daya hidup bahasa. Penelitian yang memfokuskan pada keterancaman bahasa Roswar itu menghasilkan kesimpulan bahwa vitalitas bahasa Roswar terbagi dalam tiga tingkat, yaitu stabil, mantap, tetapi berpotensi mengalami kemunduran adalah mobilitas penutur, kedwibahasaan informan, penggunaan bahasa antargenerasi, penggunaan bahasa pada ranah keluarga, penggunaan bahasa untuk mengungkapkan ekspresi perasaan, penggunaan bahasa pada ranah pemerintahan, dan sikap bahasa (kebanggaan dan kesetiaan bahasa); (2) mengalami kemunduran; dan (3) terancam. Menurut Perangin-Angin, D. M. dan Novita Dewi (2020) dalam simpulan penelitiannya yang berjudul Merawat Lagu-Lagu Daerah Pagu untuk Pemertahanan Bahasa: Analisis Ekolinguistik tertulis bahwa pemertahanan bahasa Pagu agar tidak punah dapat dilakukan melalui interaksi antar pengguna bahasa dan perawatan budaya seperti lagu-lagu rakyat.

Berdasarkan hasil kajian terhadap hasil penelitian pemertahanan bahasa tersebut, secara umum dapat dikatakan bahwa penelitian tersebut memiliki kesamaan dalam tema pemertahanan bahasa, yang membedakan hanya pada lokasi dan objek bahasa yang diteliti. Objek bahasa yang diteliti adalah bahasa Lelea. Bahasa Sunda Lelea adalah bahasa yang telah mengalami permainan bahasa homini intralingual. Bahasa Sunda Lelea menjadi bahasa yang unik yang berada di lingkungan masyarakat pemakai bahasa Sunda, bahasa Jawa, dan bahasa Indonesia. Karena keunikannya itu, bahasa Sunda Lelea perlu diteliti mengenai penggunaan bahasa Sunda Lelea dan cara pemertahanannya. Permasalahan penelitian yang akan dibahas adalah 1) bahasa 
apa yang terdapat di wilayah Lelea Indramayu, Provinsi Jawa Barat? dan 2) bagaimana cara pemertahanan bahasa Sunda Lelea oleh masyarakat tuturnya?

Tujuan dari penelitian ini adalah adanya deskripsi dan penjelasan mengenai kondisi bahasa Sunda Lelea sebagai salah satu bahasa daerah yang berkembang di wilayah Indonesia. Selain itu, tujuan penelitian ini adalah untuk menemukan solusi pemertahanan bahasa tersebut sebagai upaya pemertahanan dari kepunahan bahasa-bahasa daerah yang menjadi aset budaya Indonesia.

Urgensi dari penelitian ini adalah ditemukannya salah satu bahasa daerah dari ratusan bahasa daerah yang berkembang di Indonesia. Penelitian ini akan menjadi tambahan khazanah pengetahuan khususnya rumpun bahasa Sunda, yang mana selama ini bahasa Sunda yang kita kenal hanya ada di Priangan yang disebut sebagai bahasa Sunda Priangan.

\section{LANDASAN TEORI}

Bahasa khususnya bahasa daerah di manapun berada akan mengalami perubahan, yakni bergeser pada bahasa lain melalui proses akulturasi atau punah karena tidak ada yang mempertahankannya. Crystal (2014) menuliskan hasil kajiannya terhadap bahasa di Arizona, yaitu "Kita mengetahui banyak, mengenai mengapa suatu bahasa terancam punah dan mati, dan mengapa orang bergeser dari satu bahasa ke bahasa lain, tetapi kita hanya mengetahui sedikit tentang mengapa bahasa itu dipertahankan dan mengapa orang tetap setia terhadap bahasa itu. Contoh kasus pemertahanan bahasa ini ditemukan pada kelompok kecil Suku Tewa dari Arizona. Suku Tewa ini telah lama menjadi kelompok kecil di lingkungan komunitas Hopi yang dominan, tetapi bahasa suku minoritas itu menjadi kuat karena dipertahankan oleh penggunanya." Arti dari tulisan tersebut adalah bahasa itu akan punah jika tidak ada yang mempertahankan, tetapi jika ada yang mempertahankan, bahasa itu akan kuat seperti bahasa pada Suku Tewa dari Arizona.

Kepunahan suatu bahasa bisa juga terjadi oleh kebijakan pemerintah. Hal ini terjadi di Australia yang menerapkan kebijakan untuk kaum migran (dari negara-negara yang tidak berbahasa Inggris). Kebijakan ini banyak merugikan pemertahanan bahasa Aborigin. Walaupun terlambat, kemudian ada kebijakan untuk pemertahanan bahasa Aborigin mulai dari asimilasi sampai multikulturalisme yang masih berlanjut hingga saat ini. Di awal 1980-an setidaknya masih ada lebih dari 300 penutur pengguna bahasa Aborigin (Janse, 1984). Hasil penelitian tersebut menjelaskan bahwa kebijakan yang salah dalam menangani bahasa daerah akan menimbulkan kepunahan suatu bahasa.

Kepunahan suatu bahasa biasanya diikuti oleh kebangkitan suatu bahasa untuk dipertahankan. Seperti apa yang dituliskan Janse (1984) "Diskriminasi linguisida dan linguistik telah menambah daftar bahasa yang punah. Pada saat yang sama kepunahan tersebut menjadi kekuatan dalam kebangkitan kembali etnis yang merasa memiliki kesamaan identitas di antara penutur bahasa minoritas yang terancam punah. Tren global ini terjadi sekitar tahun 1970-an. Kesamaan identitas etnis sering kali menjadi pendorong peningkatan minat pemertahanan bahasa di komunitasnya". Kebangkitan ini merupakan kesadaran yang muncul dari para penutur yang memiliki kesamaan sikap berbahasa. Sikap berbahasa itu menjadi pilihan untuk tetap mempertahankan bahasa dari kepunahan.

Pemertahanan bahasa dipengaruhi oleh berbagai faktor yang terjadi pada keluarga imigran saat proses akulturasi mereka di negara tuan rumah. Untuk memahami kondisi pemertahanan bahasa, yang harus dipahami adalah proses adaptasi budaya para imigran dalam pemertahanan bahasanya (Zhang, 2008). Penjelasan Zhang tersebut menunjukkan bahwa pemertahanan bahasa itu tidak mudah. Banyak faktor yang saling memengaruhi dalam pemertahanan bahasa tersebut di antaranya proses akulturasi budaya dari kedua penutur bahasa. 
Salah satu faktor yang memengaruhi dalam pemertahanan bahasa itu adalah faktor orang tua dalam sebuah keluarga. Orang tua dapat mewariskan bahasa leluhurnya yang akan dipertahankan melalui proses sosialisasi yang panjang dan tidak mudah. Hal ini terjadi pada proses pemertahanan bahasa Cina seperti yang diungkapkan Zhang (2008), yaitu "Pemertahanan bahasa Cina sebagai bahasa rumahan pada anak-anak generasi kedua tidak terjadi secara otomatis dalam lingkungan yang dominan berbahasa Inggris. Faktor apakah yang mendorong atau menghalangi pemertahanan bahasa Mandarin pada anak-anak? Saya akan menyajikan cerita di balik pemertahanan bahasa Mandarin sebagai bahasa leluhur anak-anak dan disosialisasikan dalam keluarga Tionghoa, melalui peran orang tua Tionghoa". Pemertahanan bahasa seperti ini secara umum dideskripsikan sebagai proses tiga generasi (Fishman, 1966; Veltman, 1983; Zhang, 2008). Jadi, proses pemertahanan suatu bahasa memang tidak mudah dan tidak secara otomatis.

Pemertahanan bahasa bisa menggunakan jalur birokrasi melalui kebijakannya dan jalur teknologi sebagai sarananya. Namun, menurut Crystal (2014) "Birokrasi dan teknologi yang tepat merupakan perangkat penting dalam pemertahanan bahasa, tetapi semuanya itu tidak bisa menjadi landasannya. Landasannya harus berasal dari rumah dan lingkungan anggota komunitas itu sendiri. Dengan demikian, faktor keluarga dan lingkungan komunitasnya yang dapat melakukan pemertahanan suatu bahasa".

Pemertahanan bahasa akan sangat efisien, dalam jangka panjang, jika seseorang mulai memberikan dukungan untuk lingkungan atau budaya pada bahasa yang ditemukan dan orang tersebut memotivasi pengguna untuk menggunakan bahasanya. Promosi budaya merupakan bagian dalam menumbuhkan bahasa agar tetap tumbuh (Crystal, 2014). Dengan kata lain, pemertahanan bahasa akan berkaitan dengan sikap masyarakat bahasa pada bahasa yang digunakan. Masyarakat bahasa yang dimaksud adalah sekelompok orang sebangsa, satu turunan, satu wilayah tempat tinggal, atau yang memiliki kepentingan sosial yang sama (Chaer, 2007). Dengan demikian, jika ada sekelompok orang dalam suatu wilayah tertentu dan dalam kehidupan sehari-harinya berkomunikasi menggunakan bahasa Sunda, masyarakat tersebut bisa dikatakan sebagai masyarakat bahasa Sunda atau masyarakat tutur berbahasa Sunda. Pemertahanan menurut Kridalaksana (2008) adalah usaha dari suatu masyarakat bahasa agar bahasa yang digunakannya tetap dihargai dan dipergunakan sebagai identitas kelompok. Usaha itu bisa melalui pengajaran di sekolah, bidang kesusastraan, bidang media massa, dan bidang lainnya.

Strategi pemertahanan bahasa yang telah diurai tersebut merupakan proses sosialisasi bahasa. Yang dimaksud dengan sosialisasi menurut Nasution (2011) adalah proses membimbing individu ke dalam dunia sosial. Sosialisasi dilakukan dengan mendidik individu tentang kebudayaan yang harus dimiliki dan diikutinya agar ia menjadi anggota yang baik dalam masyarakat dan dalam berbagai kelompok khusus. Sosialisasi dapat dianggap sama dengan pendidikan, karena dalam proses sosialisasi, individu belajar tingkah laku, kebiasaan, dan pola-pola kebudayaan lainnya serta keterampilan-keterampilan sosial lainnya seperti berbahasa, bergaul, berpakaian, dan lainnya. Sosialisasi bahasa adalah proses pengenalan, pemahaman, dan penanaman bahasa ibu atau bahasa pertama yang berlaku dari suatu generasi ke generasi berikutnya. Proses sosialisasi dilakukan melalui interaksi sosial dengan cara pemberian pengetahuan dan keyakinan terhadap identitas, peran, dan fungsi sosial dari bahasa yang mereka miliki. Sosialisasi ini harus diupayakan sejak masa kanak-kanak. Sosialisasi bahasa merupakan kegiatan eksplorasi dalam berkomunikasi. Masyarakat tutur diperkenalkan pada peran dan fungsi bahasa sebagai alat komunikasi. Bagaimana peran bahasa dalam bersosialisasi dan berinteraksi di dalam lingkungan masyarakat? Bagaimana fungsi bahasa sebagai alat untuk menghibur, menuangkan gagasan, mentransfer ilmu pengetahuan, mencari informasi, dan berkomunikasi? 


\section{METODE PENELITIAN}

Penelitian ini menggunakan metode deskriptif kualitatif. Data penelitian diperoleh dari pengamatan dan informasi yang diberikan oleh informan. Penelitian ini bersifat empiris, karena dapat diamati dan dialami. Data penelitian berupa hasil pengamatan dan informasi hasil wawancara. Sumber data penelitian dipilih berdasarkan kategori yang dianggap memiliki informasi lengkap mengenai pemertahanan bahasa Lelea dan dianggap mewakili setiap unsur masyarakat. Adapun jumlah sumber datanya adalah 5 orang yang terdiri dari 2 orang pejabat desa, yaitu Rasidi (Kepala Desa Lelea) dan Bisri (Kepala Urusan Kesejahteraan Desa), 1 guru madrasah yaitu Ustadz Syuhada, 1 orang Ketua Karang Taruna Desa Lelea, yaitu Tasen, serta 1 orang pengurus PKK, yaitu Markonah. Untuk memperoleh data mengenai bahasa dan sosialisasinya tentang penggunaan Bahasa Lelea, penulis melakukan metode simak dan wawancara, yaitu dengan menyimak penggunaan bahasa pada masyarakat setempat atau masyarakat desa yang menggunakan bahasa sunda Lelea dan masyarakat pengguna bahasa jawa serta melakukan pengamatan tentang pengunaan bahasa tersebut di masyarakat. Teknik pengumpulan datanya adalah simak-libat-catat. Teknik ini dilakukan dengan cara menyimak, terlibat langsung dalam wawancara, dan mencatat hal-hal yang dianggap penting untuk data penelitian.

Instrumen pengumpulan data menggunakan 1) pedoman wawancara, yaitu untuk mendapatkan data berkaitan kebijakan-kebijakan yang dikeluarkan oleh pemerintah desa, sekolah, PKK, dan karang taruna yang berkaitan dengan penggunaan bahasa Lelea. Untuk mendapatkan data, peneliti langsung melakukan wawancara kepada sumber data yang telah ditetapkan, yaitu 2) kartu data untuk mencatat data-data berdasarkan kategori perangkat desa, sekolah, PKK, dan karang taruna. Selanjutnya, data yang didapatkan dari hasil wawancara terhadap sumber data akan dianalisis dan dipilih, kemudian dicatat pada kartu data.

Analisis data pada penelitian ini dilakukan melalui empat langkah, yaitu 1) mereduksi data, langkah ini dilakukan setelah data hasil wawancara dan pengamatan langsung pada sumber data diperoleh dengan cara memilih dan memilah data sesuai dengan kategori perangkat desa, sekolah, PKK, dan karang taruna; 2) mentranskripsikan data hasil wawancara, yaitu mencatat data yang dianggap dapat menjawab permasalahan yang ditetapkan dalam penelitian; 3) menganalisis data, dilakukan dengan cara mendeskripsikan dan menjelaskan data yang dikaitkan dengan teori pemertahanan; dan 4) menyimpulkan hasil analisis data yang berkaitan dengan rumusan masalah.

\section{PEMBAHASAN}

Masyarakat Desa Lelea berasal dari masyarakat Jawa dan Sunda yang berada di sekitar Indramayu. Ragam bahasa dialek Sunda Lelea terbentuk dari pembauran penduduk yang berbahasa Jawa dengan masyarakat perbatasan berbahasa Sunda. Bahasa Sunda Lelea berbeda dengan bahasa Sunda Priangan. Hal ini karena pembauran dengan bahasa Jawa Dermayon (Indramayu). Percampuran bahasa Sunda Lelea dengan bahasa Jawa Dermayon membentuk dialek Sunda Lelea yang memiliki ciri khas sendiri.

Walaupun dalam dialek Lelea bahasa Jawa lebih dominan, orang Lelea menyebut orang Jawa "wong wetan" dan orang Sunda adalah "wong gunung", padahal masyarakat di daerah Lelea sendiri adalah orang-orang Sunda. Sikap demikian dapat diartikan bahwa mereka menganggap dirinya bukan orang Jawa dan bukan orang Sunda, tetapi merupakan satu etnis komunitas tersendiri. Sikap demikian menurut sumber yang dikemukan oleh Samian (Tanpa Tahun: 13) baru timbul di zaman Wiralodra II yang menyatakan Lelea bagian dari Indramayu. 
Ragam bahasa dialek Sunda Lelea terbentuk dan dipengaruhi dialek Jawa Indramayu. Adapun bahasa Jawa Indramayu itu sebagai berikut.

1. Bahasa Jawa yang terdiri atas tiga tingkatan, yaitu bahasa ngoko, krama, dan krama inggil. Contoh:
lungo - kesah - tindak
artinya pergi
kowe - sampeyan - penjenengan
teko - dateng - rawuh
artinya engkau
artinya datang

Sedangkan dialek Indramayu hanya mengenal dua tingkatan, yaitu bahasa bagongan dan basan atau bebasan. Bahasa basan dipakai untuk berbicara dengan orang yang lebih tua umurnya atau orang yang lebih tinggi martabatnya. Namun, masih banyak penduduk desa di pedalaman yang tidak mengerti bahasa basan/bebasan itu.

2. Ditinjau dari bunyi bahasa, dialek Indramayu berbeda dengan bunyi dialek bahasa Jawa. Dalam bahasa Jawa semua kata yang ditulis dengan vokal "a" dibaca "o", seperti lara dibaca loro. Tidak demikian dengan dialek Indramayu bahwa vokal "a" tetap saja dibaca "a" seperti bata tetap dibaca bata.

3. Ditinjau dari sudut bahasa pergaulan, pada dialek Indramayu, kata-kata yang kotor menurut orang lain (bukan orang Indramayu) merupakan bahasa persahabatan atau pergaulan. Seperti: "Asu sira tak enten-enteni nembe teka", artinya "asu (anjing) kamu saya tunggutunggu baru datang".

Pada saat penggunaan dialek Sunda Lelea terselip Jawa Dermayon, contonya: "Gura balik inya nyuung sintren ulah lila lila", artinya "cepat pulang kamu nonton sintren jangan lama-lama". Di sini akibat pengaruh bahasa Dermayon, "eu" ditulis dan dibaca "u", kata balik adalah bahasa Dermayon yang artinya pulang. Sampai sekarang bahasa Sunda Lelea masih tetap dominan, walaupun dikatakan orang-orang gunung bahasa Sunda tersebut kasar. Masalah bahasa tersebut seperti halnya cabang-cabang kebudayaan lainnya, senantiasa mengalami evolusi, sehingga pada akhirnya terciptalah dialek Lelea yang dipakai sekarang ini.

Sebagaimana yang telah diuraikan sebelumnya, bahwa pergeseran bahasa tersebut terjadi karena kontak bahasa pada dua kelompok tutur atau masyarakat bahasa. Peristiwa ini ada yang menyebut sebagai fenomena sosiolinguistik. Kontak bahasa itu terjadi antara masyarakat pendatang dengan masyarakat pribumi. Biasanya kaum pendatang yang mulai beradaptasi dengan kaum pribumi. Mulai dari kelompok kecil sampai berkembang pada kelompok besar. Bahasa kaum pendatang perlahan bergeser pada bahasa kaum pribumi sehingga akhirnya terjadilah bahasa yang dimiliki oleh keduanya. Mereka akan memiliki dua bahasa atau disebut dwibahasawan. Peristiwa pergeseran bahasa terjadi di Desa Lelea, kecamatan Lelea, Kabupaten Indramayu, Provinsi Jawa Barat. Migrasi kelompok yang berbahasa Sunda dari luar daerah Lelea masuk pada masyarakat berbahasa Jawa Dermayon (Indramayu) telah membentuk bahasa baru yang disebut bahasa Sunda Lea (Desa Lelea). Peristiwa pergeseran bahasa ini terjadi karena adanya interaksi dan kontak bahasa yang kemudian adanya konvensi berdasarkan pada pertimbangan sosial ekonomi dan adanya status bahasa yang dianggap lebih tinggi oleh masyarakat di Desa Lelea.

Setelah terbentuknya bahasa Lea, pada perkembangan berikutnya dari masyarakat berbahasa Sunda Lea, terjadi lagi peristiwa pergeseran bahasa. Ada peristiwa migrasi di masyarakat Lelea. Migrasi yang terjadi pada masyarakat Lelea terjadi pada generasi muda. Hal ini berkaitan dengan faktor ekonomi. Kehidupan perekonomian di Desa Lelea yang lebih mengandalkan sektor pertanian dan perdagangan mengakibatkan generasi mudanya cenderung lebih memilih keluar dari Desa Lelea, yakni dengan merantau ke kota-kota besar untuk menjadi tenaga kerja dalam waktu relatif lama. Peristiwa migrasi masyarakat Lelea ke Jakarta karena tuntutan ekonomi dengan sendirinya telah menjadikan dia dwibahasawan, yaitu bahasa Sunda Lea sebagai bahasa Ibu dan bahasa Indonesia sebagai bahasa kedua hasil kontak bahasa di 
perantauannya. Pada saat mereka kembali ke daerah, beberapa anggota masyarakat bahasa Lelea ada yang merasa malu dengan bahasa Lelea sehingga mereka lebih senang dengan menggunakan bahasa Indonesia. Mereka menganggap bahwa bahasa Indonesia memiliki kedudukan dan status yang lebih tinggi karena sebagai bahasa nasional. Mereka tidak berkeberatan bahasa Indonesia digunakan dalam kegiatan-kegiatan pada pertemuan-pertemuan resmi yang bersifat tradisi.

Dengan adanya pergeseran bahasa pada masyarakat Lelea, maka masyarakat Lelea menjadi masyarakat yang multibahasa. Masyarakat Lelea mengenal dan menggunakan tiga bahasa, yaitu: selain ada B1 (bahasa Jawa dan Sunda), ada lagi B2 yaitu bahasa Indonesia. Adapun persentase penggunaan ketiga bahasa tersebut dalam peristiwa tutur dapat dilihat pada tabel 1.

Tabel 1.

Persentase Penggunaan Bahasa Lelea

\begin{tabular}{|c|c|c|c|}
\hline \multirow{2}{*}{ Kegiatan Tutur } & \multicolumn{3}{|c|}{ Penggunaan Bahasa } \\
\hline & Sunda Lelea & Jawa & Bahasa Indonesia \\
\hline Keagamaan & $\sqrt{ }$ & - & - \\
\hline Pendidikan & $\sqrt{ }$ & $\sqrt{ }$ & $\sqrt{ }$ \\
\hline Pemerintahan Desa & $\sqrt{ }$ & - & - \\
\hline Keluarga & $\sqrt{ }$ & - & - \\
\hline Kekariban & $\sqrt{ }$ & $\sqrt{ }$ & - \\
\hline Perdagangan & $\sqrt{ }$ & $\sqrt{ }$ & - \\
\hline Kebudayaan & $\sqrt{ }$ & - & - \\
\hline PKK & $\sqrt{ }$ & - & - \\
\hline Kepemudaan & $\sqrt{ }$ & - & $\sqrt{ }$ \\
\hline Persentase (\%) & 100 & 33 & 22 \\
\hline
\end{tabular}

Tabel 1 menunjukkan bahwa bahasa Sunda Lelea menjadi bahasa ibu dan bahasa utama bagi masyarakat Desa Lelea. Semua kegiatan tutur menggunakan bahasa Sunda Lelea. Fenomena ini yang menarik dari bahasa Lelea. Bahasa yang terbentuk dari dua bahasa melalui proses akulturasi yang kemudian membentuk bahasa baru sebagai alat komunikasi antara kaum migran dengan pribumi. Bahasa ini kemudian menjadi bahasa daerah yang baru dan diakui menjadi bahasa ibu bagi generasi berikutnya. Adapun bahasa Jawa sebagai bahasa yang digunakan pada kegiatan perdagangan dan pendidikan. Hal ini disebabkan adanya pembauran kelompok pada kegiatan tersebut, sehingga kedua bahasa itu digunakan sebagai proses alih kode dalam berkomunikasi. Demikian juga dengan bahasa Indonesia yang hanya digunakan pada kegiatan yang bersifat nasional dan resmi seperti pada kegiatan pendidikan dan pengajaran di sekolah serta kegiatan kepemudaan yang komunitasnya ada keberagaman yang menuntut adanya alih kode.

Penggunaan lebih dari satu bahasa dalam suatu komunitas dan hidup secara berdampingan merupakan peristiwa bahasa yang menunjukkan para penggunanya bersikap positif terhadap kehidupan bahasa tersebut. Crystal (2014) menyebutkan bahwa bilingualisme yang sehat adalah keadaan dua bahasa sebagai bahasa yang saling melengkapi, bukan dalam persaingan mendapatkan peran yang berbeda, tetapi dilihat dari perspektif kebermanfaatannya. Itulah keragaman bahasa yang ada dan terjadi di daerah Lelea Indramayu.

Seperti bahasa-bahasa daerah lainnya, ketika ada peristiwa migrasi kaum pendatang dan adanya interaksi kaum pribumi dengan masyarakat luar, pergeseran bahasa pasti terjadi. Peristiwa pergeseran bahasa yang tejadi pada generasi muda Lelea, berakibat pada terjadinya perubahan dan pergeseran bahasa Lelea itu sendiri. Bahasa Lea atau Lelea bisa jadi mengikuti bahasa-bahasa daerah lainnya, yaitu mengalami kepunahan. Ketika generasi muda mereka yang kembali dari perantauannya dan mereka lebih senang menggunakan bahasa Indonesia, tidak mustahil kepunahan itu terjadi. Banyak ranah sosial seperti ranah keagamaan, pendidikan, pemerintahan desa, keluarga, kekariban, perdagangan, kebudayaan, PKK, dan Karang Taruna 
yang tadinya menggunakan bahasa Lelea, mungkin akan bergeser menggunakan bahasa Indonesia.

Pergeseran bahasa adalah proses yang alami. Pergerakan penutur apakah proses migrasi atau akulturasi akan menyebabkan bahasa itu mengalami perubahan. Perubahan yang terjadi bisa melemahkan bahkan menghilangkan, bisa juga menguatkan. Hal ini tergantung pada masyarakat pengguna bahasa Lelea itu sendiri. Apakah mau mempertahankan bahasa itu sebagai identitas daerahnya atau membiarkan bahasa yang telah dibentuknya punah seiring perkembangan generasinya. Tentu saja, masyarakat yang mencintai bahasanya akan tetap menjaga dan mempertahankan bahasanya itu sebagai warisan turun temurun dari generasi ke generasi. Seperti petikan wawancara antara peneliti dengan ibu Markonah (pengurus PKK) dan ustad Syuhada (guru mengaji) berikut ini yang menunjukkan ada itikad baik untuk mempertahankan bahasa Lelea.

\begin{tabular}{|c|c|}
\hline Peneliti & $\begin{array}{l}\text { :"Bagaimana penggunaan bahasa di sekolah pada saat } \\
\text { melaksanakan KBM?" }\end{array}$ \\
\hline Ibu Maskonah & $\begin{array}{l}\text { "'Ya, tergantung kondisi, Bu, biasanya kami } \\
\text { menggunakan bahasa Sunda sebagai bahasa pengantar } \\
\text { di sekolah. Kalau ada siswa yang memakai bahasa } \\
\text { Jawa, ya kita menjawab dengan bahasa Jawa, tetapi bila } \\
\text { siswa menggunakan bahasa Sunda, ya kita pakai } \\
\text { bahasa Sunda. }\end{array}$ \\
\hline Ustad Syuhada & $\begin{array}{l}\text { : "Ya, di madrasah juga begitu. Karena siswa berasal dari } \\
\text { desa yang pakai bahasa Sunda dan Jawa. Bahasa di sini } \\
\text { disebut Bahasa Sunda Lea yang berbeda dengan bahasa } \\
\text { Sunda lainnya. }\end{array}$ \\
\hline Peneliti & $\begin{array}{l}\text { : "Supaya Bahasa Sunda Lea itu tidak punah, bagaimana } \\
\text { peran tokoh masyarakat di sini?” }\end{array}$ \\
\hline Ibu Maskonah & $\begin{array}{l}\text { :"Ya, kita terapkan pada setiap ada acara, misalnya arisan } \\
\text { ibu-ibu, PKK, pengajian, dan lain sebagainya. }\end{array}$ \\
\hline
\end{tabular}

Percakapan tersebut menunjukkan bahwa bahasa Sunda Lelea menjadi bahasa ibu dan bahasa Jawa menjadi bahasa kedua. Untuk menjaga bahasa Sunda Lelea itu tidak punah, maka diterapkan kebijakan penggunaan bahasa Sunda Lelea pada berbagai kegiatan seperti arisan, PKK, pengajian, dan lain-lain.

Menurut Bisri (Kaur Kesra desa) menjelaskan bahwa masyarakat Desa Lelea memegang teguh penggunaan bahasa Lelea terutama kalangan tua sebagai bentuk pemertahanan bahasa. Hal itu disebabkan bahasa Sunda Lelea adalah bahasa Sunda yang memiliki keunikan akibat adanya percampuran dengan bahasa Jawa. Bahasa ini terbentuk sejak zaman Wilalodra.

Informasi lain dari Rasidi (Kepala Desa Lelea) yang menjelaskan bahwa masyarakat Lelea masih menggunakan bahasa tersebut dalam berbagai kegiatan, baik formal maupun non formal. Dalam setiap kegiatan, pemerintahan desa selalu menggunakan bahasa Sunda Lelea (Sunda Lea) di samping bahasa Indonesia. Hal ini untuk menjaga dan mempertahankan kelestarian bahasa tersebut sebagai salah satu aset kebudayaan daerah. Salah satu contohnya ada pada upacara adat Ngarot yang biasa diadakan setiap tahun pada hari Rabu bulan Desember. Dimulai dari tata upacara penyambutan sampai acara inti menggunakan bahasa Sunda Lelea (Sunda Lea). Upacara adat Ngarot ini adalah upacara adat menyambut musim tanam di daerah agraris. Kegiatannya berupa prosesi arak-arakan pemuda dan pemudi yang berhias dan beragam pakaian menuju balai desa. Kegiatan ini untuk menanamkan sikap peduli pertanian pada generasi muda.

Pemertahanan bahasa Sunda Lelea dilakukan juga oleh karang taruna desa tersebut. Selain kegiatan Ngarot yang melibatkan generasi muda dalam mempertahankan bahasa Sunda Lea. Pemuda karang taruna pun berusaha untuk melakukan kegiatan-kegiatan sosialisasi 
pemertahanan bahasa. Hal itu dijelaskan Tasen, seorang pengurus karang taruna dalam wawancara dengan peneliti. Dalam penjelasannya, dia mengatakan bahwa masyarakat Desa Lelea masih memegang teguh penggunaan bahasa Sunda Lelea (Sunda Lea) dalam kehidupan sehari-hari, walaupun terkadang tercampur dengan bahasa lainnya misalnya bahasa Indonesia ataupun lainnya.

\begin{tabular}{|c|c|}
\hline Peneliti & $\begin{array}{l}\text { : "Bagaimana penggunaan bahasa Sunda Lea di kalangan } \\
\text { anak muda di desa ini?" }\end{array}$ \\
\hline Tasen & $\begin{array}{l}\text { " "Anak karang taruna di sini biasa menggunakan memakai } \\
\text { Bahasa Sunda Lea, walaupun kadang-kadang mereka } \\
\text { juga menggunakan bahasa Indonesia." }\end{array}$ \\
\hline Peneliti & $\begin{array}{l}\text { :"Lalu, adakah keinginan untuk mensosialisasikan bahasa } \\
\text { ini kepada generasi muda lainnya." }\end{array}$ \\
\hline Tasen & $\begin{array}{l}\text { "Ya, kami sedang berusaha, antara lain agar dalam setiap } \\
\text { kegiatan karang taruna kami memakai bahasa Sunda } \\
\text { Lea, kemudian ada keinginan agar bahasa Sunda Lea } \\
\text { bisa menjadi muatan lokal karena kebetulan saya juga } \\
\text { peduli pada pendidikan. }\end{array}$ \\
\hline
\end{tabular}

Isi percakapan tersebut menunjukkan hal-hal sebagai berikut.

(1) Bahasa Sunda Lelea (Sunda Lea) merupakan bahasa asli masyarakat hasil percampuran antara bahasa Sunda yang dipengaruhi bahasa Jawa Dermayon.

(2) Penggunaan bahasa Sunda (Sunda Lea) dilakukan pada kegiatan-kegiatan sosial antara lain PKK, pengajian, kenduri, upacara adat, dan lainnya.

(3) Ada upaya untuk menjadikan bahasa Sunda sebagai muatan lokal di sekolah.

Deskripsi data tersebut menjelaskan bahwa Bahasa Lelea (Sunda Lea) diupayakan untuk dijaga dan dipertahankan sebagai bahasa utama untuk berkomunikasi di lingkungan masyarakat Desa Lelea, Kecamatan Lelea Kabupaten Indramayu. Adapun cara pemertahananya adalah sosialisasi melalui keluarga, komunitas, dan kebijakan pemerintah daerah melalui kegiatan budaya, PKK, dan pendidikan.

Aktivitas sosialisasi yang dilakukan masyarakat bahasa Lelea adalah dengan cara melakukan berbagai aktivitas yang di dalamnya ada penyertaan bahasa sebagai alat berkomunikasinya. Aktivitas ini tentu saja akan menjadi proses pembiasaan bagi pengguna bahasa. Melalui pembiasaan itu, dengan sendirinya bahasa yang mereka gunakan akan melekat dan menjadi identitas masyarakat tutur di daerah tersebut. Kegiatan bernalar, bercerita, menuangkan gagasan, proses transfer pengetahuan merupakan kegiatan-kegiatan sosialisasi bahasa yang bisa dilakukan dalam mempertahankan bahasa. Adapun sosialisasi yang dilakukan oleh masyarakat Sunda Lelea adalah adanya kebijakan penggunaan bahasa Sunda Lelea pada berbagai kegiatan. Tabel 2 berikut ini menunjukkan sosialisasi yang dilakukan.

Tabel 2.

\begin{tabular}{ll}
\multicolumn{1}{c}{ Kegiatan } & Sosialisasi Bahasa Sunda Lelea \\
\hline Keluarga & \multicolumn{1}{c}{ Bentuk Sosialisasi } \\
\hline Keagamaan & Penggunaan bahasa ibu dalam keluarga \\
\hline Pendidikan & Pengajian, Khutbah Jumat \\
\hline Pemerintahan Desa & KBM di sekolah umum dan madrasah \\
\hline Kebudayaan & Kegiatan rapat, penyuluhan ke warga \\
\hline PKK & Perayaan acara adat, misalnya:upacara Ngarot \\
\hline Kepemudaan & Arisan ibu-ibu \\
\hline
\end{tabular}

Tabel 2 tersebut menggambarkan bentuk sosialisasi yang dilakukan oleh masyarakat tutur bahasa Sunda Lelea sebagai upaya pemertahanan bahasa Sunda Lelea sebagai bahasa Ibu. Pada kegiatan keagamaan, mereka menggunakan bahasa Sunda Lelea pada setiap kegiatan pengajian dan khotbah Jumat. Sosialisasi ini efektif karena kegiatan ini adalah kegiatan rutin yang dihadiri oleh masyarakat, baik muda maupun tua. Melalui kegiatan itu, proses transfer 
bahasa Ibu khususnya ke generasi muda akan terjadi. Generasi akan menerima dan tertanam dalam memorinya struktur bahasa Sunda Lelea.

Sosialisasi pada kegiatan pendidikan terjadi pada proses kegiatan belajar mengajar di sekolah umum atau madrasah. Di Desa Lelea, bahasa pengantar pengajaran menggunakan bahasa Sunda Lelea, sedangkan bahasa Jawa dan bahasa Indonesia dilakukan pada saat komunikasi yang memerlukan bahasa itu. Misalnya, bahasa Indonesia digunakan pada saat menjelaskan materi dari sumber yang berbahasa Indonesia.

Setiap elemen masyarakat terutama aparat pemerintahan desa menyadari betul peran dan fungsinya dalam mempertahankan bahasa Sunda Lelea. Oleh karena itu, pemerintahan desa melakukan sosialisasi bahasa melalui kegiatan-kegiatan resmi, misalnya dalam pelayanan kepada masyarakat sekitar, mereka membiasakan diri dengan berbahasa Sunda Lea dengan tujuan agar Bahasa Lea menjadi ikon dari masyarakat desa tersebut.

Kegiatan kebudayaan adalah salah satu sarana efektif untuk sosialisasi bahasa. Seperti yang telah diulas sebelumnya, yaitu upacara adat Ngarot. Kegiatan budaya itu menjadi sarana pemertahanan bahasa dan budaya serta penyampaian nilai-nilai luhur yang wajib dijunjung. Nilai-nilai leluhur yang menjadi nilai kearifan lokal Desa Lelea itulah yang akan memberikan ikon atau ciri khas masyarakat Desa Lelea.

Kegiatan berkumpul ibu-ibu di pedesaan bisa menjadi sarana untuk mensosialisasikan bahasa. Oleh karena itu, kegiatan $P K K$ ibu-ibu di Desa Lelea dijadikan sarana untuk mempertahankan bahasa Lelea dengan cara bahasa yang digunakan pada kegiatan itu menggunakan bahasa Sunda Lelea.

Karang taruna adalah kegiatan kepemudaan atau organisasi kepemudaan di desa. Dalam upaya sosialisasi bahasa Lelea agar tetap dikenal dan dihayati oleh anggota masyarakatnya, terutama generasi muda, maka pemerintahan desa bekerja sama dengan Organisasi Karang Taruna Desa Lelea mengadakan kegiatan sebagai upaya pemertahanan bahasa Lelea agar tetap lestari. Kegiatan tersebut antara lain:

1. Penggunaan bahasa Sunda Lelea pada setiap pertemuan dan mengadakan kegiatankegiatan seperti:

a. lomba bahasa Lelea;

b. setiap tanggal 17 Agustus selalu diadakan kegiatan yang lebih bersifat kebersamaan yang menjalin hubungan komunikasi dengan menggunakan bahasa Sunda Lelea;

c. Rencana Pemuda Pemudi Karang Taruna Desa Lelea bersama pemerintah desa (Kuwu) membuat Kamus Sunda Lelea.

\section{Komunikasi Teman Sebaya}

Kalangan pemuda Lelea menggunakan bahasa Sunda Lelea dengan teman-teman sebayanya. Para pemuda setelah pergi merantau tetap menggunakan bahasa Lelea sekembalinya dari rantau ke desa.

3. Komunikasi di Lingkungan Keluarga

Sosialisasi bahasa ibu yang paling strategis adalah pemakaiannya pada lingkungan keluarga. Di lingkungan keluarga inilah bahasa ibu sebagai bahasa pertama dikenal dan diperoleh oleh kanak-kanak. Hal ini seperti yang dikemukakan Chaer (2010) yang menjelaskan proses pemerolehan bahasa (akuisisi bahasa) pertama oleh seorang anak. Menurutnya proses pemerolehan bahasa ibu itu berlangsung di dalam otak seseorang saat masih anak-anak. Pemerolehan bahasa kedua terjadi melalui proses pembelajaran. Ada dua proses dalam perolehan bahasa Lelea sebagai bahasa pertama di lingkungan keluarga, yaitu proses kompetensi dan performansi. Proses kompetensi adalah proses penguasaan tata bahasa, walaupun tidak disadari. Proses performansi adalah proses pemahaman dan produksi kalimat. Oleh karena itu, pemerolehan bahasa di lingkungan keluarga sesungguhnya meliputi pemerolehan semantik, pemerolehan sintakis, dan pemerolehan 
fonologi. Ketiga komponen tersebut diperoleh secara bersamaan. Pemerolehan dan pemakaian bahasa Lelea di lingkungan keluarga masyarakat Lelea tidak menggunakan bahasa yang mengenal undak usuk dengan tiga tingkatan, yaitu bahasa ngoko, krama, dan krama inggil, yang penerapan pemakaiannya disesuaikan dengan tingkat umur dan lebih tinggi status sosialnya (martabatnya).

Dalam masyarakat bahasa Lelea hanya mengenal bahasa dialek Indramayu dengan dua tingkatan tingkatan, yaitu bahasa bagongan dan basan atau bebasan. Sebagaimana yang telah di jelaskan di atas bahwa bahasa basan dipakai untuk berbicara dengan orang yang lebih tua umurnya atau orang yang lebih tinggi martabatnya. Namun, masih banyak penduduk desa di pedalaman yang tidak mengerti bahasa bebasan itu. Oleh karena itu, ada yang berpendapat bahwa bahasa Lelea tidak mengenal undak usuk.

4. Rencana Mulok

Perencanaan bahasa daerah akan dilakukan secara profesional dan institusional dengan memasukan di lembaga-lembaga pendidikan sebagai muatan lokal. Bahasa Sunda Lelea diharapkan dijadikan salah satu kebijakan politik nasional mengenai bahasa daerah, sehingga bisa dijadikan salah satu materi pelajaran di sekolah sebagai muatan lokal.

Dari data tersebut sudah tergambar jelas bahwa sebagian besar masyarakat Desa Lelea bersikap untuk terus berupaya mempertahankan eksistensi bahasa Sunda Lea melalui berbagai bentuk kegiatan sosialisasi. Hal tersebut merupakan sikap bahasa, sesuai dengan apa yang dikemukakan Garvin dan Mathiot (1968) yang kutip Chaer \& Agustina (2010), yaitu:

(1) Language loyalty (kesetiaan bahasa), sikap ini berkaitan dengan itikad dari masyarakat pengguna bahasa untuk tetap menggunakan bahasa ibu dan berusaha mempertahankan dari berbagai pengaruh bahasa yang lain;

(2) Language pride (kebanggaan bahasa), sikap ini berkaitan dengan perasaan bangga terhadap bahasa sendiri dan menggunakan bahasa tersebut sebagai identitas masyarakatnya;

(3) Awareness of the norm (kesadaran norma bahasa), sikap ini berkaitan dengan pemahaman bahwa alam bahasa itu ada norma sehingga perlu memperhatikan santun berbahasa.

Ketiga sikap bahasa tersebut akan mendukung upaya masyarakat Desa Lelea untuk mempertahankan bahasanya sebagai bahasa ibu dan bahasa utama dalam berbagai kegiatan tindak tutur di lingkungannya. Sosialisasi yang dilakukan pada berbagai kegiatan merupakan perwujudan dari sikap bahasa yang positif. Dengan demikian, bahasa Sunda Lelea (Sunda Lea) tidak akan ikut punah seperti bahasa-bahasa daerah lainnya.

\section{PENUTUP}

Proses pergeseran bahasa yang melibatkan kaum pendatang dan pribumi bisa terjadi dari kelompok kecil sampai berkembang pada kelompok besar. Hal inilah yang terjadi pada penutur kaum pribumi bahasa Jawa Dermayon, yang bahasanya tergeser oleh bahasa pendatang, bahasa Sunda, yang kemudian membentuk bahasa baru yang disebut bahasa Lelea. Ragam bahasa Sunda Lelea (Sunda Lea) adalah ragam bahasa yang unik bila dibandingkan dengan ragam bahasa Sunda priangan. Keunikannya itu disebabkan oleh adanya bentuk baru dari percampuran bahasa antara bahasa Sunda dan bahasa Jawa Dermayon. Bahasa itu membentuk dialek tersendiri yang disebut dialek Lelean yang berbeda dari bahasa Sunda dan bahasa Jawa asalnya.

Penggunaan bahasa Sunda Lea digunakan pada semua aktivitas di Desa Lelea, mulai dari kegiatan keagamaan, pendidikan, pemerintahan desa, keluarga, kekariban, perdagangan, 
kebudayaan, PKK, dan kepemudaan. Bahasa Jawa dan bahasa Indonesia menjadi bahasa pendamping untuk memperlancar komunikasi antarwarga. Bahasa Sunda Lelea sebagai bahasa ibu disikapi positif oleh penuturnya melalui upaya pemertahanan bahasa yang dilakukan masyarakat dan pemerintah Desa Lelea. Upaya tersebut dilakukan dalam bentuk sosialisasi bahasa dalam berbagai kegiatan. Bentuk sosialisasi yang dilakukan adalah 1) kegiatan dalam keluarga di rumah; 2) kegiatan keagamaan: pengajian dan khotbah Jumat; 3) pendidikan: KBM di sekolah umum dan madrasah; 4) pelayanan pemerintahan desa: kegiatan rapat dan penyuluhan ke warga; 5) kebudayaan: perayaan acara adat, misalnya upacara Ngarot dan pernikahan; 6) PKK: arisan ibu-ibu; dan 7) kepemudaan: acara karang taruna.

Apapun strategi yang dilakukan dalam pemertahanan bahasa Sunda Lelea, akan kembali pada sikap bahasa penuturnya. Strategi itu hanya sebuah upaya. Apabila strategi itu dilaksanakan dengan pilihan sikap positif dengan cara mencintai pada bahasanya, maka bahasa itu akan tetap hidup. Sebaliknya, apabila strategi itu tidak dilaksanakan, maka perlahan bahasa itu akan mengalami kepunahan.

\section{DAFTAR PUSTAKA}

Arikunto, Sumarsini. (2010). Prosedur Penelitian. Jakarta: Rineka Cipta.

Awala, Norsimah Mat, Mohammad Fadzeli Jaafarb, Mohammed Azlan Misc, Hayati Latehd. (2013). Maintenance of Mother Tongue: Patterns of Language Choice at the Malaysian-Thai Border: dalam The Authors. Published by Elsevier Ltd.

Chaer, Abdul. (2007). Linguistik Umum. Jakarta: Rineka Cipta.

Chaer, Abdul dan Leonie Agustina. (2010). Sosiolinguistik Perkenalan Awal. Jakarta: Rineka Cipta.

Crystal, David. (2014). Language Death. Cambridge: United Kingdom Cambridge University Press. https://doi.org/10.1017/CBO9781139923477

Hudson, R.A. (1999). Sociolinguistics. Cambridge: University press.

Janse, Mark. (1984). Language Death and Language Maintenance Theoretical, Practical and Descriptive Approaches. Linguistic Bibliography. Ghent University: University of Amsterdam.

Kholidah, Umi.(2015). Pemertahanan Bahasa Jawa pada Interaksi Siswa dan Guru dalam Pembelajaran Kajian Sosiolinguistik di MTs Al-Hikmah Pasir Demak. Ranah 4(2). Desember 2015.

Kridalaksana, Harimurti. (2008). Kamus Linguistik. Jakarta: PT. Gramedia Pustaka Utama.

Mbete, Aron Meko. (2010). Strategi Pemertahan Bahasa-Bahasa Nusantara: dalam Prosiding Pemertahanan Bahasa Nusantara. 1-11. http://eprints.undip.ac.id/36865/1/1.pdf

Mujid FA dan Suyanto. (2017). Pergeseran dan Pemertahanan Bahasa Ibu dalam Ranah Rumah Tangga Migran di Kota Semarang. NUSA. 12(1). Februari 2017. https://doi.org/10.14710/nusa.12.1.15-26

Muslihah, N.N, Rusmana Dewi, Lessy Puspitasari. (2018). Pemertahanan Bahasa Sindang pada $\begin{array}{lllll}\text { Masyarakat Kota Lubuklinggau. Jurnal } & \text { KIBASP. }\end{array}$ https://doi.org/10.31539/kibasp.v2i1.458

Nasution. (2011). Sosiologi Pendidikan. Jakarta: Bumi Aksara.

Nurhayati, Endang, Mulyana, Hesti Mulyani, dan Suwardi. (2013). Strategi Pemertahanan Bahasa Jawa di Provinsi Daerah Istimewa Yogyakarta. Litera, Jurnal Penelitian Bahasa, Sastra, dan Pengajarannya. 12(1). April 2013. https://doi.org/10.21831/ltr.v12i01.1338

Perangin-Angin, D. M. dan Novita Dewi. (2020). Merawat Lagu-Lagu Daerah Pagu untuk Pemertahanan Bahasa: Analisis Ekolinguistik. Ranah: Jurnal Kajian Bahasa. 9(2). 272-286. https://doi.org/10.26499/rnh.v9i2.2932 
Rahardi, Kunjana. (2010). Kajian Sosiolinguistik. Bogor: Ghalia Indonesia.

Putri, Rani Anisa, dkk. (2018). Pemertahanan Bahasa Bali dalam Ranah Keluarga dan Ranah Agama di Desa Sedahan Jaya. Jurnal Pendidikan dan Pembelajaran Khatulistiwa. 7(7). https://jurnal.untan.ac.id/index.php/jpdpb/article/view/26493/75676577228

Samian. (2002). Sejarah Desea Lelea. Laporan Penelitian: Indramayu.

Sudarma, T. Fatimah Djaja, Wahya, Elvi Citraresmana, Dian Indira, Teddi Muhtadin, dan Hera Meganova Lyra, (2015) Upaya Pemertahanan Bahasa-Budaya Sunda di Tengah Pengaruh Globalisasi dalam Makalah Pengabdian Masyarakat, Fakultas Ilmu Budaya Universitas Padjadjaran.

Sumarsono. (2012). Sosiolinguistik. Yogjakarta: SABDA.

Widianto, Eko. (2018). Pemertahanan Bahasa Daerah Melalui Pembelajaran dan Kegiatan di Sekolah. Jurnal Kredo. 1(2). April 2018. https://doi.org/10.31933/ujes.2.1.071$\underline{081.2018}$

Wijana, I Dewa Putu. (2006). Sosiolinguistik, Kajian Teori dan Analisis. Yogyakarta: Pustaka Pelajar.

Yulianti, Santi dan Winci Firdaus. (2020). Keterancaman Bahasa Roswar: Analisis Daya Hidup Bahasa. Ranah: Jurnal Kajian Bahasa. 9(2). 358-373. https://doi.org/10.26499/rnh.v9i2.2942

Zhang, Donghui. (2008). Between Two Generations Language Maintenance and Acculturation among Chinese Immigrant Families. LFB Scholarly: Publishing LLC El Paso. 